University of Nebraska - Lincoln

DigitalCommons@University of Nebraska - Lincoln

Agronomy \& Horticulture -- Faculty Publications

Agronomy and Horticulture Department

November 1968

\title{
Rhizome and Tiller Development of Kentucky Bluegrass (Poa pratensis L.) as Influenced by Photoperiod, Cold Treatment, and Variety
}

Lowell E. Moser

University of Nebraska-Lincoln, Imoser1@unl.edu

S. R. Anderson

R. W. Miller

Follow this and additional works at: https://digitalcommons.unl.edu/agronomyfacpub

Part of the Plant Sciences Commons

Moser, Lowell E.; Anderson, S. R.; and Miller, R. W., "Rhizome and Tiller Development of Kentucky Bluegrass (Poa pratensis L.) as Influenced by Photoperiod, Cold Treatment, and Variety" (1968). Agronomy \& Horticulture -- Faculty Publications. 86.

https://digitalcommons.unl.edu/agronomyfacpub/86

This Article is brought to you for free and open access by the Agronomy and Horticulture Department at DigitalCommons@University of Nebraska - Lincoln. It has been accepted for inclusion in Agronomy \& Horticulture -Faculty Publications by an authorized administrator of DigitalCommons@University of Nebraska - Lincoln. 


\title{
Rhizome and Tiller Development of Kentucky Bluegrass (Poa pratensis L.) as Influenced by Photoperiod, Cold Treatment, and Variety ${ }^{1}$
}

\author{
L. E. Moser, S. R. Anderson, and R. W. Miller ${ }^{2}$
}

\section{ABSTRACT}

Two controlled environment experiments were designed to study the effect of photoperiod and a cold treatment on rhizome and tiller development of 'Merion' and 'Windsor' Kentucky bluegrass (Poa pratensis L.) Evidence is given to support the following conclusions:

1. A cold treatment is not essential for rhizome formation. Cold treatments increased tillering but reduced the number of rhizomes.

2. Both initiation and elongation of rhizomes were favored by a 16- or 18-hour photoperiod when compared to a 8- or 12- hour photoperiod.

3. Tillering showed little response to initial photoperiod, although more tillers were formed with a 12-hour than with an 8- or 18-hour photoperiod in one experiment.

4. Windsor generally produced more and longer primary and secondary rhizomes than Merion but the latter tillered more profusely than Windsor.

Additional index words: Kentucky bluegrass, photoperiod, rhizome, tiller, turf, Poa pratensis L., day length, Merion, Windsor.

M ANY studies concerning the influence of environment on rhizome development by Kentucky bluegrass (Poa pratensis L.) have not been carefully controlled. Much has been inferred from field studies. The controlled environment experiments reported here were designed to gain information about the ef-

${ }^{1}$ Published with the permission of the Associate Director of the Ohio Agricultural Research and Development Center as Journal Article no. 18-68. Received March 29, 1968.

${ }^{2}$ Formerly graduate student (now Assistant Professor), formerly Professor (now Dean of Agriculture, Texas A \& I University, Kingsville), and Associate Professor, respectively, Department of Agronomy, The Ohio State University, Columbus 43210 and Ohio Agricultural Research and Development Center, Wooster. fect of photoperiod, a cold treatment, and variety on rhizome production by Kentucky bluegrass.

Several authors have reported that Kentucky bluegrass generally does not produce an appreciable number of rhizomes until late spring of the year following seeding $(2,3)$. In the autumn another period of new rhizome production occurs although production is less than in spring $(3,4)$. Under field conditions most rhizomes were reported to be produced by Kentucky bluegrass at the time of year when the photoperiod is the longest ${ }^{3}(2,3)$. Differences in numbers of rhizomes were not always great, but the ratio of rhizomes to shoots was about three times greater for plants grown under long photoperiods than for plants grown under short ones. ${ }^{3}$ Rhizome and stolon growth of zoysia increased as photoperiod lengthened with rhizome growth reaching a peak at 14-hour photoperiods (11). Kentucky bluegrass produces more tillers under short than under long days ${ }^{3}(7,9)$. Some authors have stated that Kentucky bluegrass appears to require a winter season before any appreciable rhizome production occurs ${ }^{4}(10)$.

'Windsor' and 'Merion' Kentucky bluegrass were selected for these studies. Nittler (8) reported that in the seedling state Windsor had a greater number and length of rhizomes than Merion and that Merion had four times as many tillers as 'Newport.' Others have reported a rather large difference between Kentucky

\footnotetext{
${ }^{3}$ M. W. Evans. 1937. Ann. Report of Forage Crop Investigations, Wooster, Ohio.

${ }^{4}$ R. B. Musgrave, 1940. Life history of Poa pratensis L. Ph.D. Thesis. University of Illinois.
} 
bluegrass selections in their ability to produce rhizomes $^{5}(6)$.

\section{MATERIALS AND METHODS}

\section{Experiment I. Photoperiod}

Merion and Windsor Kentucky bluegrass were planted in the greenhouse in $23 \times 30 \mathrm{~cm}$ flats containing a mixture of two parts muck to one part silty loam soil. The experimental design was a randomized complete block with three replications. While in the greenhouse, the natural photoperiod ranged from approximately 15.5 to 16 hours. Twenty days after emergence, the plants were thinned to four plants per flat and moved to controlled environment chambers where they were subjected to 8-, 12-, and 18-hour photoperiods. A separate growth chamber was used for each photoperiod. The lights were cool white fluorescent with interspersed incandescents, and the intensity was about 26,900 lux at the soil surface. Temperature was held constant both day and night at 20 to $21 \mathrm{C}$, which has been reported to be nearly optimum for rhizome production (1, 3). Plants were clipped at $14 \mathrm{~cm}$ to a height of $9 \mathrm{~cm}$. The experiment was terminated 69 days after emergence. An average of the four plants in each flat was used in data analyses.

\section{Experiment II. Photoperiod and Cold Treatment}

The second experiment was divided into a rhizome initiation phase and a rhizome development phase. Treatments were varied in the initiation phase and were identical in the development phase. From the literature it was concluded that rhizomes seemed to grow best under long photoperiods so a 16-hour photoperiod and a constant 20 to $21 \mathrm{C}$ were used in the development phase. The same controlled environment chambers were used in this experiment as in Experiment $I$.

Merion and Windsor Kentucky bluegrass were planted in the chambers in $4 \mathrm{~cm}$ peat pots containing muck and exposed to 8-, 12-, and 16-hour photoperiods. After emergence the plants were thinned to one per pot. Twenty-eight days after emergence half of the plants were placed in a cold chamber at the respective photoperiods with a constant temperature of 0 to $2 \mathrm{C}$ (cold treated). The other half remained in the original chamber at 20 to $21 \mathrm{C}$ (not cold treated).

After 10, 20, 30 and 40 days of such cold treatment, the respective plants were transferred to the development chamber. Four of the plants were placed in a $23 \times 30-\mathrm{cm}$ flat containing a mixture of two parts silty loam soil, one part concrete sand, and one part peat. Four grams of ammonium nitrate were sprinkled over the top of each flat. This procedure was followed for both varieties at each photoperiod and each temperature treatment at the end of the designated number of days of cold treatment. Plants were not clipped during the course of this study. The plants remained in the development chamber for 30 days before harvesting.

This experiment was conducted separately for the 8-hour, the 12-hour, and the 16-hour photoperiods. The design was completely randomized with three replications. An average of the four plants in each flat was used in the data analyses.

\section{RESULTS}

\section{Photoperiod}

A greater number of primary rhizomes was produced per plant under the longest photoperiod than under either the 8- or 12-hour photoperiods. Primary rhizomes are those initiating at the crown of the original plant. When the photoperiod was varied only in the rhizome initiation phase more rhizomes were present on plants receiving 16 -hour photoperiods than on those receiving shorter ones. The number of secondary rhizomes, although not great on any plants in these short duration studies, increased in both experiments as the photoperiod lengthened (Fig. 1 and 2). Sec-

${ }^{5}$ E. J. Melcherson, 1963. Comparative performance of vegetative and seedling bluegrasses for turf. M.S. Thesis. Purdue University.

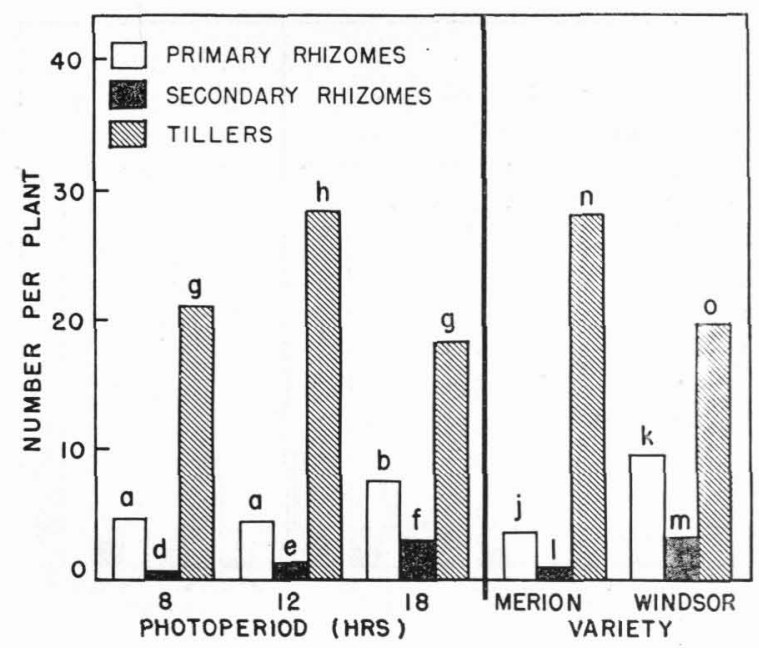

Fig. 1. (Experiment I) - Effect of photoperiod and variety on rhizome and tiller numbers of Kentucky bluegrass. Duncan's multiple range applicable to within parameter within variable only $(5 \%$ level $)$.

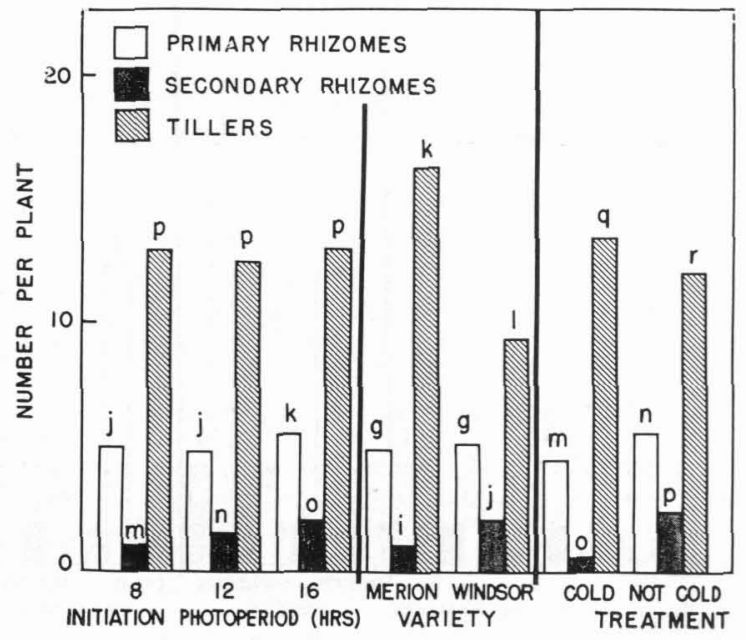

Fig. 2. (Experiment II) - Effect of initiation photoperiod, variety, and cold on rhizome and tiller numbers of Kentucky bluegrass. Duncan's multiple range applicable to within parameter within variable only $(5 \%$ level $)$.

ondary rhizomes are those that originate as a branch of a primary rhizome or originate from an emerged primary rhizome.

Rhizomes elongated more rapidly under long photoperiods than under shorter ones. Total primary and secondary length increased as the photoperiod was extended in both experiments. Average primary and secondary rhizome length was less at an 8-hour photoperiod than at longer periods (Fig. 3 and 4).

In these short term experiments, few primary rhizomes emerged. In Experiment. I, the greatest percentage of primary rhizomes emergence occurred at a 12-hour photoperiod and no significant difference existed at the $5 \%$ level between the 8- or 18-hour treated plants (Fig. 5). In Experiment II, there was little difference in primary rhizome emergence (Fig. $6)$.

The length of the initiation treatment produced little effect on any of the parameters measured. Generally the parameter increased with treatment time al- 


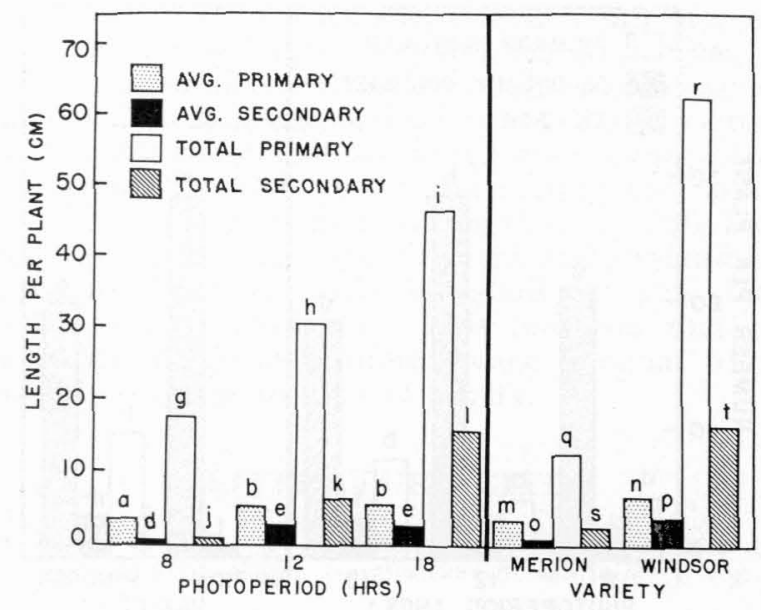

Fig. 3. (Experiment I) - Effect of photoperiod and variety on rhizome length of Kentucky bluegrass. Duncan's multiple range applicable to within parameter within variable only $(5 \%$ level $)$.

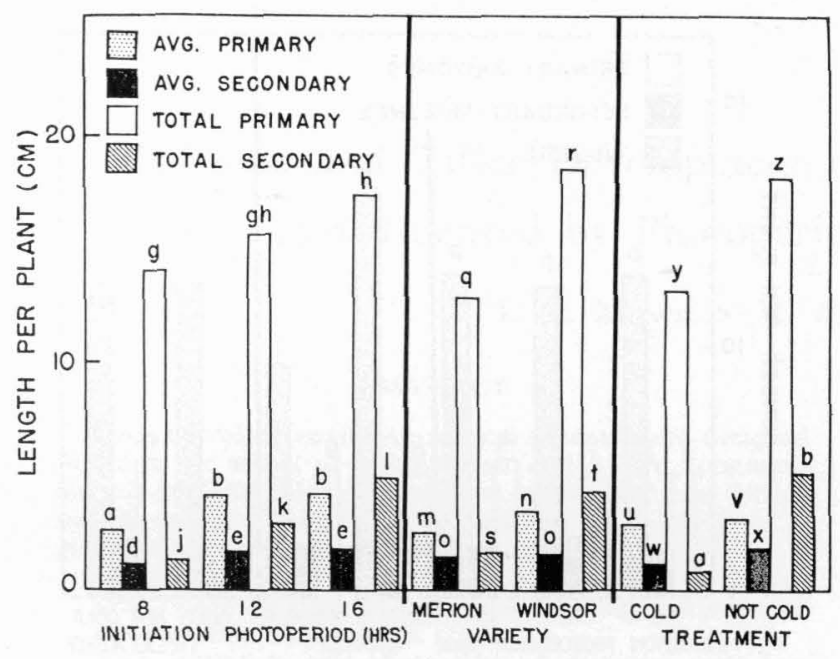

Fig. 4. (Experiment II) - Effect of initiation photoperiod, variety and cold on rhizome length of Kentucky bluegrass. Duncan's multiple range applicable to within parameter within variable only ( $5 \%$ level).

though in some instances there was rather erratic response to initiation treatment length. No critical amount of cold or photoperiodic treatment required to initiate rhizomes or tillers was determined.

Long photoperiods favored rhizome differentiation more than tiller differentiation. Crown buds as shown in Fig. 5 and 6 are the sum of primary rhizomes and tillers. In both experiments the percentage of developed crown buds forming primary rhizomes was greater at the longest photoperiod and no significant difference existed between the 8- or 12-hour treated plants. The number of tillers produced per plant was greater under a 12-hour photoperiod than an 8-or 18-hour period in Experiment I. The length of the initiation photoperiod had little effect on the number of tillers per plant in Experiment II.

\section{Cold Treatment}

Plants cold treated in the rhizome initiation phase had fewer and shorter rhizomes than those not cold

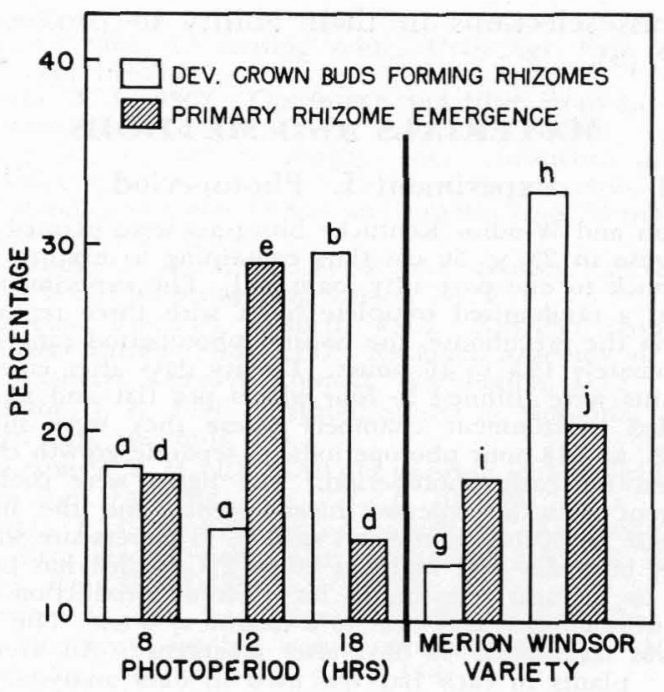

Fig. 5. (Experiment I) - Effect of photoperiod and variets on rhizome emergence and percentage of developed crown buds that were rhizomes. Duncan's multiple range applicable to within parameter within variable only ( $5 \%$ level).

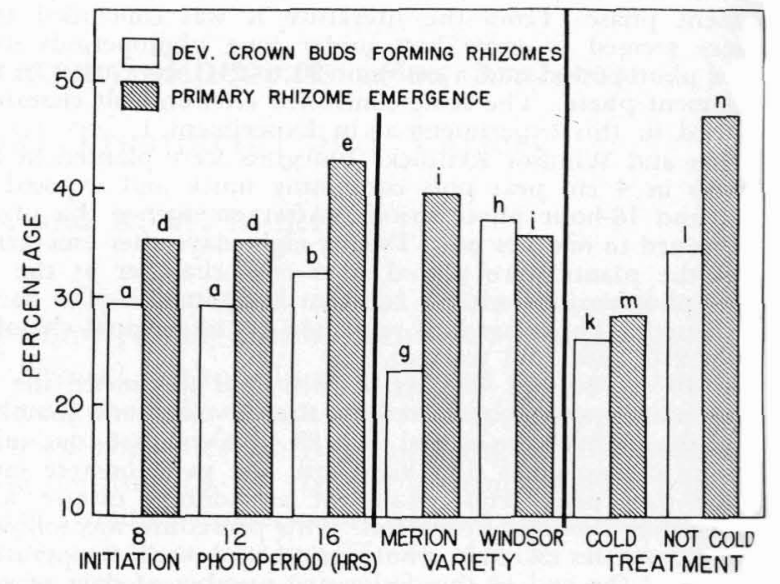

Fig. 6. (Experiment II) - Effect of initiation photoperiod, variety and cold on rhizome emergence and percentage of the developed crown buds that were rhizomes. Duncan's multiple range applicable to within parameter within variable only (5\% level).

treated. Cold treatment reduced the number-of primary rhizomes and produced a comparable increase in tiller numbers (Fig. 6).

The number and length of rhizomes and the percent age of crown buds developing into rhizomes increased with a long photoperiod when plants were not cold treated. Cold treated plants responded little to vary. ing photoperiod. There was also an interaction of cold treatment and photoperiod with respect to tiller production. With an 8-hour photoperiod, plants not cold treated had more tillers than cold treated plants, but as the initiation photoperiod was lengthened above 8 hours, the cold treated plants had more tillers than those not cold treated.

\section{Variety}

In Experiment I Windsor had more primary thizomes than Merion, although in Experiment II Wind- 
sor and Merion did not differ significantly in the number of primary rhizomes. In both experiments, Windsor had a greater number of secondary rhizomes than Merion (Fig. 1, 2). Windsor had longer rhizomes, and more of the developed crown buds were differentiated into rhizomes than was the case with Merion. Percentage of primary rhizome emergence was about the same for both varieties. Merion tillered much more profusely than Windsor (Fig. 2,6).

In Experiment II, the number of primary rhizomes increased on Merion but not on Windsor as the initiation photoperiod was extended. In Experiment I where all of the plants' development occurred in different photoperiods, Windsor responded more in rhizome numbers and length to longer photoperiods than Merion. In Experiment 1, the number of tillers produced per plant increased markedly on Merion as the photoperiod was lengthened from 8 to 12 hours and decreased sharply with a further extension to 18 hours. Windsor responded in the same manner but to a lesser degree. In Experiment II the number of tillers of Windsor decreased gradually and those of Merion increased as photoperiod was lengthened although the differences were small.

\section{DISCUSSION}

These controlled environment experiments showed that primary and secondary rhizomes initiate and elongate better under long rather than short photoperiods. This is in agreement with inferences made from field studies reported previously $(2,3,4)$ and with Younger (11) who reported that rhizome and stolon weights of zoysia were increased by long photoperiods. In Kentucky bluegrass short photoperiods and a cold treatment alone or in combination are not necessary for rhizome initiation as Lindsey and Peterson (5) found them to be for flowering. Kentucky bluegrass does not have to pass through a winter before an appreciable number of rhizomes form as has been implied by previous authors ${ }^{4}$ (10). Under natural conditions, Kentucky bluegrass usually passes through a winter before many rhizomes form; but this is not a requirement to trigger rhizome initiation. Cold treatment reduced rhizome numbers and length because the plants developed very little while in the cold chamber. Plants that were not cold treated were further developed morphologically even though both groups of plants were the same age at the time of transfer from the rhizome initiation to the development phase.

Tiller initiation is greater under medium photoperiods than under long or short ones. Maximum tiller numbers occurred at a 12 -hour photoperiod in Experiment I which is nearly equal to the photoperiod at which Lindsey and Peterson (5) and Peterson and Loomis (9) obtained the greatest tiller production from: Kentucky bluegrass. Cold treatment did not enhance or reduce crown bud initiation but shifted their differentiation slightly. More crown buds differentiated into tillers and fewer into rhizomes with a cold treatment than without one.
There are genetic differences between Kentucky bluegrass selections that account for variations in productions of rhizomes and tillers ${ }^{5}(6,8)$. The rhizome production of Merion and Windsor in these studies followed the same trends as those reported by Nittler (8) on young Kentucky bluegrass seedlings. Although Merion had the same number of primary rhizomes as Windsor in Experiment II, many of them were very short and emerged very close to the original crown. In these experiments Merion appeared to be more of a bunch type grass than did Windsor. The four Windsor plants filled the flat with a mat of roots and rhizomes more quickly than Merion. Less varietal difference would be expected in a solid turf although varieties with many long rhizomes would be expected to knit more quickly after seeding and fill voids rapidly.

Merion and Windsor had about the same number of developed crown buds (primary rhizomes and tillers), but Merion had a greater number differentiated into tillers and Windsor had a greater differentiated into rhizomes. Lobenstein (6) described general types of growth by Kentucky bluegrass. He reported that Merion produced a large number of tillers and generally short rhizomes that emerge close to the original crown. In the two experiments reported here, Merion generally fits this description. Most of the Windsor plants fit the description of Lobenstein's (6) 16-B or 16-H clones. Windsor produced fewer tillers than Merion but produced a greater number of long rhizomes. Turf thickening occurred when rhizomes emerged and tillered. At the same time the potential for a new cycle of rhizomes was produced.

\section{LITERATURE CITED}

1. Brown, E. M. 1939. Some effects of temperature on the growth and chemical composition of certain pasture grasses. Mo. Agr. Exp. Sta. Res. Bull. 299.

2. Etter, A. G. 1951. How Kentucky bluegrass grows. Ann. Mo. Bot. Gard. 38:293-375.

3. Evans, Morgan W. 1949. Vegetative growth, development, and reproduction in Kentucky bluegrass. Ohio Agr. Exp. Sta. Res. Bull. 681.

4. Hanson, A. A. and E. V. Juska. 1961. Winter root activity in Kentucky bluegrass (Poa pratensis L.) Agron. J. 53:372-374.

5. Lindsey, K. E. and M. L. Peterson. 1964. Floral induction and development in Poa pratensis L. Crop Sci. 4:540-544.

6. Lobenstein, C. W. 1964. Sod-forming characteristics of Kentucky bluegrass as affected by morphological and physiological factors. Ph.D. Diss. Purdue Univ. (Libr. Congr. Card No. Mic. 64-12, 764) 110 p. Univ. Microfilms. Ann Arbor, Mich. (Diss. Abstr. 25:3195-3196).

7. Lovvorn, R. L. 1945. The effect of defoliation, soil fertility, temperature, and length of day on the growth of some perennial grasses. J. Amer. Soc. Agron. 37:570-582.

8. Nittler, L. W. 1966. Seedling characteristics useful in identifying Kentucky bluegrass. Farm Res. 32(1):14-15.

9. Peterson, M. L., and W. E. Loomis. 1949. Effects of photoperiods and temperature on growth and flowering of Kentucky bluegrass. Plant Physiol. 24:31-43.

10. Thatcher, L. E., C. J. Willard, and R. D. Lewis. 1937. Better methods of seeding meadows. Ohio Agr. Exp. Sta. Bull. 588.

11. Younger, V. B. 1961. Growth and flowering of Zoysia species in response to temperature, photoperiods, and light intensities. Crop Sci. 1:91-93. 